\title{
Teaching NeuroImages: All Hemiparesis Are Not Contralateral
} Y. Muralidhar Reddy, DM (Neurology), ASN (Certification), Subhendu Parida, DM (Neuroradiology), and
Jagarlapudi M.K. Murthy, DM (Neurology), FAAN

Neurology ${ }^{\circledR}$ 2021;96:e478-e479. doi:10.1212/WNL.0000000000010755

\author{
Correspondence \\ Y. Muralidhar Reddy \\ muralidharnims@gmail.com
}
Figure 1 MRI Axial Images Showing Diffusion Restriction and Corresponding ADC Reversal Suggestive of Acute Infarct in Left Inferior Parietal Lobe (A-B); FLAIR Showing Gliotic Scar in Left Parietal Lobe (C); Angiogram Showing Left M2 Stenosis (D)

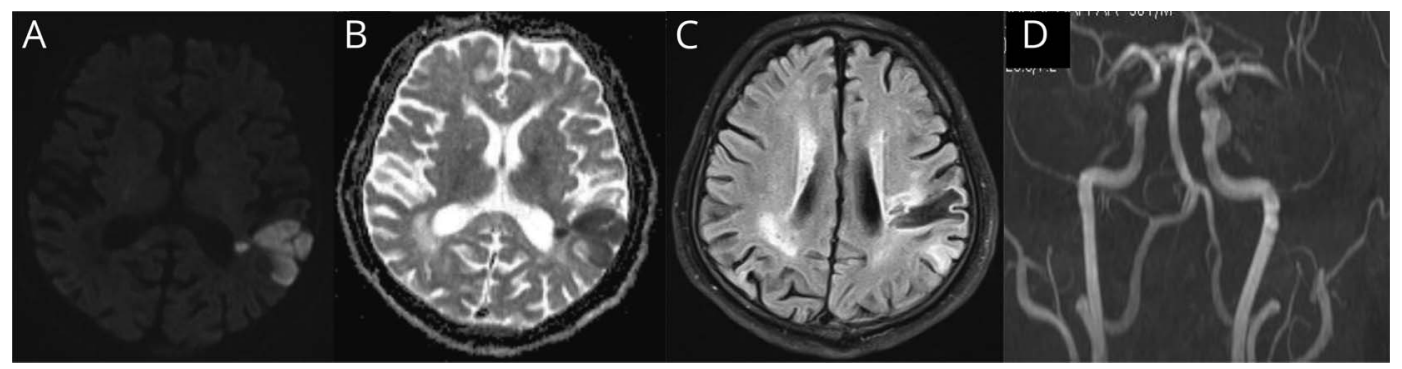

A 56-year-old hypertensive man presented with left-sided weakness of 2-hour duration. He made complete recovery from right hemiparesis because of left parietal infarct. Examination showed dysarthria and left hemiparesis (NIHSS 8/42). MRI brain showed both left parietal acute infarct and gliosis from old infarct (Figure 1). He was successfully thrombolyzed with intravenous alteplase. Present stroke was diagnosed as ipsilateral hemiparesis, confirmed by diffusion tensor imaging (Figure 2). Ipsilateral hemiparesis, mostly seen with posterior fossa malformations and remote infarctions, ${ }^{1}$ results from injury to uncrossed corticospinal tract (CST) in patients of remote brain injury or with no decussation of CST or injury to ipsilateral extrapyramidal motor pathway. ${ }^{2}$

\section{Acknowledgment}

The authors thank Dr. Suresh, MD, and Dr. Mahmood, MD, for assistance in compiling the pictures.

\section{Study Funding}

No targeted funding reported.

\section{Disclosure}

The authors report no disclosures relevant to the manuscript. Go to Neurology.org/ $\mathrm{N}$ for full disclosures.

\section{MORE ONLINE}

$\rightarrow$ Teaching slides

links.lww.com/WNL/

B204 
Figure 2 Diffusion Tensor Imaging Showing Normal Decussation of Pyramidal Tracts in Caudal Medulla in Normal Subjects (A); No Decussation in the Given Case (B-C)
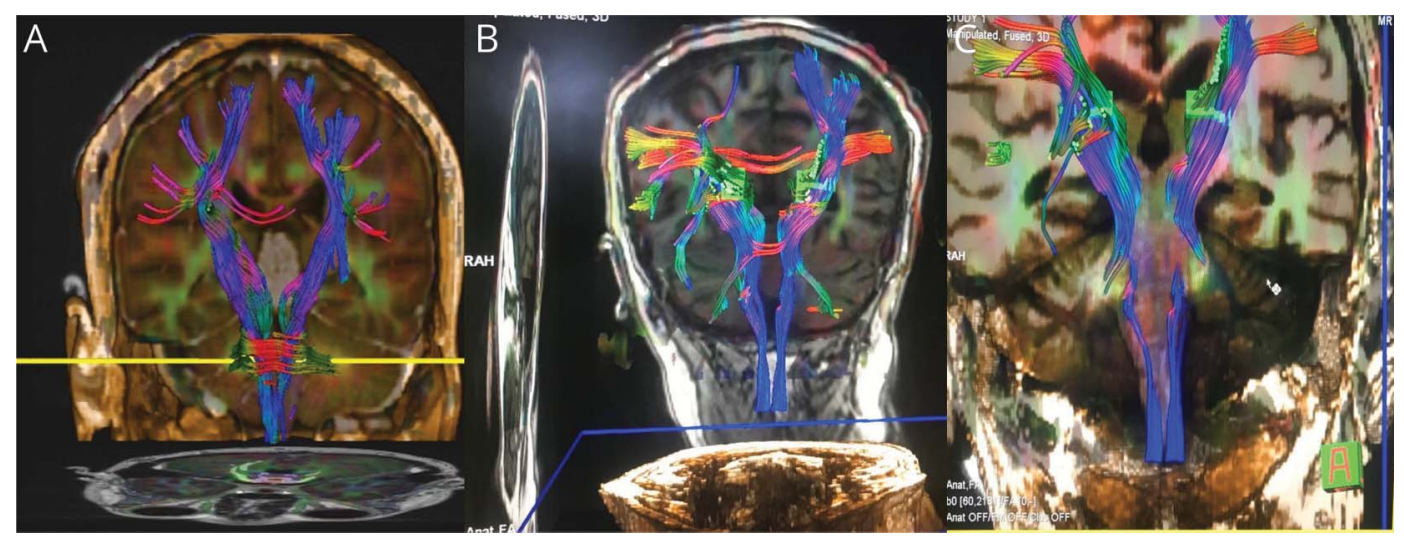

\section{Appendix Authors}

\begin{tabular}{lll}
\hline Name & Location & Contribution \\
\hline $\begin{array}{l}\text { Y. Muralidhar Reddy, } \\
\text { DM }\end{array}$ & $\begin{array}{l}\text { Care Hospital, } \\
\text { Hyderabad, India }\end{array}$ & $\begin{array}{l}\text { Conceptualized and } \\
\text { drafted the manuscript }\end{array}$ \\
\hline $\begin{array}{l}\text { Subhendu Parida, } \\
\text { DM }\end{array}$ & $\begin{array}{l}\text { Care Hospital, } \\
\text { Hyderabad, India }\end{array}$ & Drafted the figures \\
\hline $\begin{array}{l}\text { Jagarlapudi M.K. } \\
\text { Murthy, DM, FAAN }\end{array}$ & $\begin{array}{l}\text { Care Hospital, } \\
\text { Hyderabad, India }\end{array}$ & $\begin{array}{l}\text { Revision of the } \\
\text { manuscript }\end{array}$ \\
\hline
\end{tabular}

\section{References}

1. Saada F, Antonios N. Existence of ipsilateral hemiparesis in ischemic and hemorrhagic stroke: two case reports and review of the literature. Eur Neurol 2014;71:25-31.

2. Inatomi $\mathrm{Y}$, Nakajima M, Yonehara T, Ando Y. Ipsilateral hemiparesis in ischemic stroke patients. Acta Neurol Scand 2017;136:31-40. 


\title{
Neurology
}

\author{
Teaching NeuroImages: All Hemiparesis Are Not Contralateral \\ Y. Muralidhar Reddy, Subhendu Parida and Jagarlapudi M.K. Murthy \\ Neurology 2021;96;e478-e479 Published Online before print September 4, 2020 \\ DOI 10.1212/WNL.0000000000010755
}

This information is current as of September 4, 2020

Updated Information \&

Services

References

Subspecialty Collections

Permissions \& Licensing

Reprints including high resolution figures, can be found at: http://n.neurology.org/content/96/3/e478.full

This article cites 2 articles, 0 of which you can access for free at: http://n.neurology.org/content/96/3/e478.full\#ref-list-1

This article, along with others on similar topics, appears in the following collection(s):

All Cerebrovascular disease/Stroke

http://n.neurology.org/cgi/collection/all_cerebrovascular_disease_strok e

All Clinical Neurology

http://n.neurology.org/cgi/collection/all_clinical_neurology

DWI

http://n.neurology.org/cgi/collection/dwi

Infarction

http://n.neurology.org/cgi/collection/infarction

MRI

http://n.neurology.org/cgi/collection/mri

Information about reproducing this article in parts (figures,tables) or in its entirety can be found online at:

http://www.neurology.org/about/about_the_journal\#permissions

Information about ordering reprints can be found online:

http://n.neurology.org/subscribers/advertise

Neurology ${ }^{\circledR}$ is the official journal of the American Academy of Neurology. Published continuously since 1951, it is now a weekly with 48 issues per year. Copyright (C 2020 American Academy of Neurology. All rights reserved. Print ISSN: 0028-3878. Online ISSN: 1526-632X.

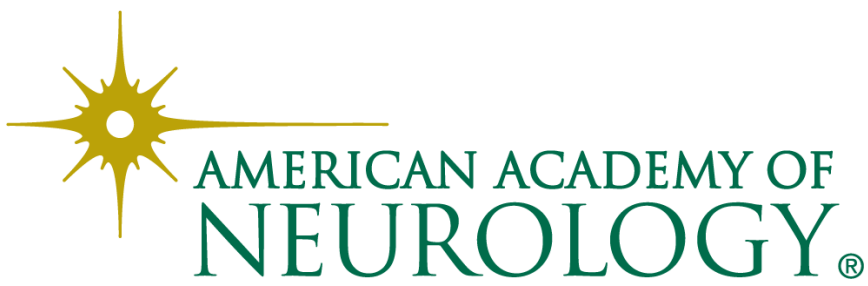

